Putkamer Joanna, Napierała Marek, Pezala Malgorzata, Zukow Walery. Characteristics morphological features of basketball players from Club "Baton Basket 25 Bydgoszcz". Pedagogy and Psychology of Sport. 2015;1(1):27-40. eISSN pending. DOI

http://dx.doi.org/10.5281/zenodo.44540

http://apcz.umk.pl/czasopisma/index.php/PPS/article/view/12217

\title{
Original Text
}

Putkamer Joanna, Napierała Marek, Pezala Malgorzata, Zukow Walery. Characteristics morphological features of basketball players from Club "Baton Basket 25 Bydgoszcz". Journal of Health Sciences. 2014;4(14):201-212. ISSN 1429-9623 / 2300-665X. DOI: http://dx.doi.org/10.13140/2.1.4298.1445 http://iournaLrsw.edu.pl/index.php/JHS/article/view/2014\%3B4\% 2814\% 29\%3A201-212 https://pbn.nauka.gov.pl/works/513144

The journal has had 5 points in Ministry of Science and Higher Education of Poland parametric evaluation. Part B item 1107. (17.12.2013).

This article is published with open access at Licensee Open Journal Systems of Radom University in Radom, Poland Open Access. This article is distributed under the terms of the Creative Commons Attribution Noncommercial License which permits any noncommercial use, distribution, and reproduction in any medium, provided the original author(s) and source are credited. This is an open access article licensed under the terms of the Creative Commons Attribution Non Commercial License (http:///creativecommons.org/icenses/by-nc/3.0/) which permits unrestricted, non commercial use, distribution and reproduction in any medium, provided the work is properly cited. This is an open access article licensed under the terms of the Creative Commons Attribution Non Commercial License (http://creativecommons.org/licenses/by-nc/3.00) which permits unrestricted, non commercial use, distribution and reproduction in any medium, provided the work is properly cited.

Conlict of interest: None declared. Received: 15.102015. Revised 05.112015. Accepted. 30.11.2015.

\section{CHARAKTERYSTYKA CECH MORFOLOGICZNYCH} KOSZYKAREK Z KLUBU „BATON BASKET 25 BYDGOSZCZ"

\section{Characteristics morphological features of basketball players from Club "Baton Basket 25 Bydgoszcz"}

\author{
Joanna Putkamer, Marek Napierała, Małgorzata Pezala, Walery Zukow
}

Kazimierz Wielki University, Bydgoszcz, Poland Uniwersytet Kazimierza Wielkiego w Bydgoszczy

Keywords: build somatic, somatic indicators of the body, basketball Slowa kluczowe: budowa somatyczna,

wskaźniki ciała, koszykarki Abstract

The aim of the study was to present the morphology of the basketball sports club,, Baton Basket 25 Bydgoszcz ". The study joined 12 players playing at 1 league. The following indicators were defined: slim body shape, BMI, arm muscle ratio, Pigneta indicator, the indicator of the pelvis, shoulders indicator, the indicator of the trunk, the rate of lower limb.

Conclusions: All are characterized by the type of basketball leptosomatic, have BMI at normal weight, stocky frame predominates $(75 \%)$, construction is characterized by a very strong $50 \%$ of basketball players, $25 \%$ of the construction stands out very strong and $25 \%$ of the average construction players, all basketball players have a long torso, pelvis narrow, narrow shoulders and represent a short limbs.

\section{Streszczenie}

Celem badań było przedstawienie budowy morfologicznej koszykarek z klubu sportowego „Baton Basket 25 Bydgoszcz”. Do badań przystąpiło 12 zawodniczek grających na poziomie 1 ligi. Określone zostały następujące wskaźniki: smukłość sylwetki ciała, wskaźnik BMI , wskaźnik umięśnienia ramienia, wskaźnik Pigneta, wskaźnik miednicy, wskaźnik barków, wskaźnik tułowia, wskaźnik kończyny dolnej.

Wnioski: wszystkie koszykarki charakteryzują się typem leptosomatycznym, posiadają wartość wskaźnika BMI na poziomie wagi prawidłowej, przeważa ramie krępe (75\%), budową bardzo mocną charakteryzuje się 50\% koszykarek, 25\% wyróżnia się budową bardzo mocną i 25\% zawodniczek budową średnią, wszystkie koszykarki posiadają długi tułów, miednicą wąską, barki wąskie i reprezentują grupę krótkokończynowych. 


\section{Wstęp}

Morfologiczne uwarunkowanie człowieka stanowi od lat problem wśród wielu trenerów jak i sportowców. Budowa ciała jak i predyspozycje wobec danej dyscypliny są bardzo skrajne. Można wyróżnić dyscypliny gdzie występują zawodnicy o skrajnej budowie ciała jak i jednorodnej budowie somatycznej zawodników w zespole. W dzisiejszych czasach przyjmuje się (...) że budowa ciała jest jednym z czynników warunkujacych osiaganie wyników sportowych na najwyższym poziomie, a jej rola w poszczególnych dyscyplinach czy konkurencjach sportowych jest różna (Drozdowski, 1979, s. 87). Uważa się że cechy morfologiczne mogą być jednym ważnych czynników w selekcji do danej dyscypliny ponieważ są łatwymi wskaźnikami do sprawdzenia czyli zmierzenia przez trenera danej dyscypliny. Obserwuje się także duże zainteresowanie budowy sylwetki sportowca przez wykształcenie do danej dyscypliny cech morfologicznych wobec osiągania danych wyników w odpowiedniej dyscyplinie sportowej jak i sprawności fizycznej specjalnej i ogólnej.

Drozdowski (1979) w swojej książce wykazuje ogólną charakterystykę cech i układów wobec wybranych dyscyplin sportowych analizując niektóre typy budowy ciała.

Do analizy rozwoju fizycznego zawodników $\mathrm{z}$ wybranych zespołów sportowych Drozdowski użył masy jak i wzrostu ciała sportowców różnych dyscyplin. W badaniu uwzględnił parametry płci męskiej polskiego pochodzenia. Średnie parametry wzrostu i ciężaru ciała danych dyscyplin są bardzo zróżnicowane względem siebie. Uważa się że zawodnicy o średnio wysokim wzroście uprawiają takie dyscypliny jak rzuty lekkoatletyczne, piłkę koszykową, piłkę siatkową, wioślarstwo, podnoszenie ciężarów i boks. Zawodnicy o nisko stosunkowym wzroście uprawiają gimnastykę jak i podnoszenie ciężarów i boks z niskich kategorii wagowych. Pod względem ciężaru ciała zawodnicy koszykówki, miotaczy, bokserów i zapaśników wykazują niski poziom masy ciała uważając ich za wyskok rosłych chodź zawodnicy niskorośli pod względem wag bokserów wykazują ta sama zależność wagową.

Pod względem powierzchni ciała Drozdowski wykorzystał pomiary wzrostu, ciężaru ciała i obwodu klatki piersiowej. Te parametry pozwalają uzyskać informacje na temat wydolności organizmu, przemiany materii jak i ustaleniu wskaźników mocy organizmu ludzkiego. Zestawienie tych badań wykazało że powierzchnia ciała wzrasta w kategorii wag u bokserów podobnie występuje u lekkoatletów-biegaczy na krótkich dystansach.

Wobec badań ciężaru właściwego ciała powstawało wiele teorii jak i wzorów do obliczania tego parametru. Zestawienie tych danych wykazało duże wahania wobec różnych dyscyplin. Sprinterzy charakteryzują się większym ciężarem właściwym ciała niż biegacze długodystansowi. Wzrost ciężaru właściwego ciała zauważa się także u bokserów, zapaśników i ciężarowców uwzględniając wyższe kategorie wagowe tych dyscyplin. Z pośród gier zespołowych koszykarze charakteryzują się najwyższa średnia ciężaru właściwego ciała.

Zróżnicowanie składu ciała zawodników z różnych zespołów sportowych wykazuje się dużą rozbieżność. W lekkoatletyce zawodnicy charakteryzujący się małą zawartością tłuszczu lecz dużą zawartością masy suchej i wody startują w biegach długich i średnich a o średniej zawartości masy suchej, wody i tłuszczu cechuje zawodników skoku wzwyż, biegu na dystansie 400m, biegu przez płotki, skoku o tyczce, w trójskoku, w biegach na krótkich dystansach i skoku w dal. Miotacze, oszczepnicy, dyskobole, pchający kulą i młociarze charakteryzują się małą zawartością masy suchej i wody lecz dużej tłuszczu. Pod względem bokserów skład ciała zwiększa się wraz z kategoria wagową. Mały udział tłuszczu w składzie ciała wykazują gimnastycy, średnie grupy lekkoatletów, skoku o tyczce oraz koszykarze. Zapaśnicy i ciężarowcy maja podobny skład ciała do bokserów z wyższych kategorii wagowych. Znaczny udział tłuszczu w składzie ciała reflektują strzelcy, łucznicy i hokeiści na lodzie. 
Pod względem zróżnicowania typologicznego powstało wiele systemów typologii somatycznej. Biorąc pod uwagę trzy typy budowy ciała, które wyróżnił Kretschmer:

typ leptosomatyczny: wąska wydłużona budowa o znacznej smukłości, mały ciężar ciała, wyraźna przewaga wymiarów długościowych nad szerokościowymi, kończyny smukłe na ogół słabo umięśnione.

typ atletyczny: silna budowa ciała, silny rozwój kośćca i mięśni.

- $\quad$ typ pikniczny: przysadzista budowa ciała, drobny szkielet, umięśnienie słabo rozwinięte, tendencja do tycia, zaokrąglona sylwetka ciała, kończyny krótkie.

Lekkoatleci dzielą się pośród tych trzech typów. Większość charakteryzuje się typem atletycznym, następnie 1/3 całości stanowią leptosomatycy a lekkoatleci startujący w pchnięciu kulą oraz rzucie młotem charakteryzują się typem budowy piknicznym. Bokserzy biorąc pod uwagę ich kategorie wagą w większości wykazują budowę atletyczną. Siatkarze jednak w większości wykazują typ budowy ciała leptosomatyczny, a gimnastycy atletyczny. Wanke wyróżnił (typ I- wzór typu leptosomatycznego u Kretschmera, typ A określa pośrednio typ leptosomatyczny oraz pikniczny u Kretschmer, typ V jest odzwierciedleniem typu piknicznego u Kretschmera, typ H jest domieszką typu piknicznego i atletycznego u Kretschmera), Kolasa uczennica Wankego wyróżniła typy dla kobiet zmieniając typ V na Y aby zachować ciągłość. Typ I przeważa u zawodników uprawiających skoki biegi lekkoatletyczne i koszykówkę i najmniej występuje u zapaśników, ciężarowców, miotaczy i gimnastyków. Natomiast typ A przeważa u średniej klasy dyskoboli, narciarzy, piłkarzy nożnych i młodych koszykarzy. Przewagę typy budowy $\mathrm{V}$ jest widoczna u czołowych zapaśników, ciężarowców oraz bokserów wagi lekkiej i lekko- półśredniej. Typ budowy $\mathrm{V}$ występuje mało u narciarzy, kolarzy oraz młodych koszykarzy. Typ budowy $\mathrm{H}$ waha się u bokserów wagi lekkiej, narciarzy oraz biegaczy na dystansie $200 \mathrm{~m}$. U kobiet te typy budowy są bardzo zmienne, na podstawie piłkarek ręcznych te typy zależą od wieku, lat trenowania i roli odgrywanej na boisku. Przewagą charakteryzuje się typ budowy V przy niedoborze typu A.

Zróżnicowanie rasowe w sporcie jest bardzo widoczne. wykazuje się ze niektóre rasy maja predyspozycje do uprawiania poszczególnych sportów. Rasa czarna wyróżnia się odmienna budowa kończyn dolnych i bardzie przystosowaną sylwetka do uprawiania biegów na krótkim dystansie. Sylwetka idealna do uprawiania gimnastyki wyróżniają się Japończycy. Można zatem wnioskować pośrednio, że poszczególne typy antropologiczne cechuje różna plastyczność, różny zakres możliwości przystosowawczych (Drozdowski, 1979, s. 129-130). Bukowski twierdzi także że cechuja się także różna budowa somatyczna (Drozdowski, 1979, s. 130).

Zróżnicowanie serologiczne także może być brane pod uwagę do selekcji sportowców wobec uprawiania różnych dyscyplin wobec wykazywania pewnych predyspozycji do silniejszego rozwoju pewnych form sprawności fizycznych.

Zróżnicowanie dermatoglificzne wobec sprawności fizycznej zaczęto także badać wobec doboru zawodników do uprawiania różnych dyscyplin. Wzięto pod uwagę linie papilarne występujące na opuszkach palców ręki pod względem łuków, pętli i wirów.

Wszystkie powyższe badania i twierdzenia cały czas były badane i rozwijane o dalsze wnioski. Jak autor zauważył: Uzyskane wyniki pozwalaja jednak oczekiwać szeregu atrakcyjnych rozwiąań, otwierających nowe możliwości poznawcze i praktycznych zastosowań $w$ selekcji kandydatów do różnych konkurencji czy dyscyplin sportowych (Drozdowski, 1979, s. 134).

Autorka Teresa Łaska-Mierzejewska uważa że , Zawodnicy wysokiego wyczynu sportowego odznaczaja się znaczna redukcja tluszczu i silnym rozwojem tkanki aktywnej" (ŁaskaMierzejewska, 1999, s. 146).

Autorka Łaska-Mierzejewska wysuwa przypuszczenia że jeżeli chcemy sprawdzić kandydata do której danej dyscypliny pasuje względem typu budowy ciała możemy się odnieść 
do:

- $\quad$ populacji nie uprawiającej sportu zawodowo.

-zawodników reprezentujących najwyższy poziom w kraju czyli kadry narodowej.

- $\quad$ zestawienie zawodnika na tle drużyny.

-reprezentacje odnosi się do olimpijczyków danej dyscypliny (Laska- Mierzejewska, 1999).

W dzisiejszych czasach można oszacować wzrost jaki osiągnie zawodnik gdy dojrzeje. Do prognozy tej metody wykorzystuje się (...) wysokość ciata dziecka w momencie dokonywania prognozy, tempo jego dojrzewania, a ponadto wysokość ciała rodziców, typ budowy ciała i inne (Łaska-Mierzejewska, 1999, s. 113). Warunki środowiskowe także mają wpływ na wykorzystanie genetycznego potencjału wzrostowego.

\section{Antropometria na usługach sportu}

Antropometria jest jedną z metod antropologii która zajmuje się pomiarem i opisem ludzkiego ciała. Poprzez antropometrie możemy badać rozwijający się organizm ludzki oraz kontrolować jego prawidłowy rozwój do ukierunkowanej aktywności ruchowej. Pomiarów różnych odcinków ludzkiego ciała dokonuje się w oparciu o odpowiednio zdefiniowane punkty antropometryczne (Drozdowski, 2002, s. 110). Także W pomiarach ludzkiego ciała postugujemy się różnymi specjalistycznym instrumentarium (Drozdowski, 1979, s. 112). Za zadanie antropometrii określa się (...) pomiar ciała ludzkiego w sytuacjach wtaściwych specyficznym formom podwyższonej aktywności ruchowej (Drozdowski,1998, s. 57).

Uważa się że antropometria sportowa powinna obejmować: -podstawowe pomiary wielkościowe ciała takie jak długość, szerokość, obwody, -pomiary wobec ćwiczeń fizycznych, rozwój poszczególnych deformacji np. koślawość kolan albo rozwoju danego mięśnia, -pomiar składu ciała przez analizę laboratoryjną, -badania pod względem właściwego ciężaru ciała (Drozdowski,1998). Do sprawności fizycznej rozumianej także jako sprawność ruchowa możemy wyodrębnić podstawowe cechy motoryczne takie jak siła, szybkość zwinność, gibkość, zręczność, oraz wytrzymałość. Wszystkie te wcześniej wyodrębnione cechy motoryczne możemy sprawdzić wszelakich testach tzw. pomiarach sprawności fizycznej. Ale także trzeba pamiętać że (...) sprawność zależy od budowy i funkcji narządu ruchu, uzdolnień i umiejętności ruchowych oraz od stanu i funkcji innych układów, wydolności fizycznej, budowy ciała, wieku, ptci, czynników psychicznych (Malinowski, Bożiłow,1997, s. 473).

Wyróżnia się także pojęcie (...) sprawność fizycznej specjalnej rozumiemy poziom zaawansowania określonych umiejętności $w$ dyscyplinach $i$ konkurencjach sportowych (Drozdowski, 1998, s. 118). Która dzieli się na 3 podgrupy w jednej pod grupie zespołów takich jak pchnięcie kula lub tez skok na odległość w sposób oczywisty i łatwy możemy odmierzyć wynik, do następnej podgrupy należą takie konkurencje jak gimnastyka artystyczna lub taniec gdzie miernik nie jest już tak łatwy do zmierzenia ale przyznaje się za określony układ lub akt ruchowy określona liczbę punktów. Do trzeciej podgrupy zaliczamy (...) zespolowe gry sportowe, w których wynik jest wypadkową osobistej sprawności fizycznej poszczególnych członków zespołu oraz swego rodzaju zespołowej umiejętności (Drozdowski,1998, s. 118-119). Wynik końcowych poszczególnych meczy jest określany poprzez zdobyte bramki, punkty albo kosze który jest wymiarem możliwości zespołu jak i czynnikiem indywidualnym. W zespołowych grach sportowych (...) pomiaru sprawności specjalnej zwykle dokonuje się rozktadajac caly ruch na jego elementy składowe, nadajace się do oceny lub pomiaru (Drozdowski,1998, s. 119) oraz dokonuje się podziału dużych fragmentów gry na mniejsze elementy, czy też specjalne skonstruowane ćwiczenia, które odzwierciedlaja najbardziej typowe sytuacje wystepujace $w$ czasie sportowej walki (Drozdowski,1998, s. 118). Najczęściej ocenia się sprawność za pomoca 
testów, czyli prób mierzonych poszczególne elementy składowe jej struktury (Malinowski, Bożiłow, 1997, s. 473).

\section{Metody, techniki, narzędzia badawcze}

W badaniach budowy ciała zawodniczek posługiwano się metodami pomiarowymi wg wskazówek nauki antropometrii.

Wysokość ciała zawodniczek zmierzono poprzez użycie miary umieszczonej przy wagach lekarskich po uprzednim sprawdzeniu $\mathrm{z}$ dokładnością do $0,1 \mathrm{~cm}$. Zawodniczka stawała w pozycji wyprostowanej, boso ze stopami złączonymi, w stroju sportowym, głowa trzymana prosto bez zadarcia ani pochylona, wzrok skierowany przed siebie. Wysokość odczytywana została od szczytu głowy badanego tzw. vertex.

Masę ciała zawodniczek określono za pomocą wagi lekarskiej z dokładnością do 10 dag. Zawodniczka wchodziła na wagę boso w stroju sportowym. Pomiary dokonano z dokładnością do $0,1 \mathrm{~kg}$. Wykorzystując pomiary wysokości i masy ciała obliczono smukłość sylwetki.

Smuktość sylwetki ciala zbadano poprzez wskaźnik Rohrera z wykorzystaniem klucza Curtiusa i charakterystyki Kretschmera, według poniższych wzorów: _ masa ciała $\mathrm{w}$ gramach $\times 100$

\section{Charakterystyka środowiska i materiał badań}

Badania antropometryczne przeprowadzono w hali sportowej przy ul. Glinki $79 \mathrm{w}$ Bydgoszczy. W badaniach skorzystano z pomocy fizjoterapeuty i profesjonalnego pokoju.

W badaniach wzięło udział 12 zawodniczek grających w rozgrywkach Pierwszej Ligi Centralnej Kobiet w sezonie 2013/2014 w klubie „Baton Basket 25” Bydgoszcz. Wiek zawodniczek waha się $\mathrm{w}$ przedziale od 18 do 22 lat. Większość dziewcząt to studentki $\mathrm{i}$ uczennice liceum. Zawodniczki zakończyły swoja przygodę $\mathrm{w}$ tzw. rozgrywkach młodzieżowych i stawiają pierwsze kroki w dorosłej, profesjonalnej koszykówce. Część z nich ma okazje trenować z ekstraklasą oraz być w jej składzie. Średnio zawodniczki swoją przygodę z koszykówką zaczynały mając 10 lat. Wszystkie dziewczęta, które reprezentujące klub „Baton Basket 25" Bydgoszcz nie pochodzą $\mathrm{z}$ tego miasta i nie są wychowankami tego klubu. Zawodniczki aktualnie trenują pięć razy w tygodniu nie wliczając w to weekendowych meczy. Trening jest zróżnicowany ponieważ w skład niego wchodzi siłownia, przygotowanie motoryczne oraz odnowa biologiczna po meczu.

Udział w badaniach wzięły zawodniczki zdrowe, które co pól roku przechodzą specjalistyczne badania sportowe umożliwiające im udział $\mathrm{w}$ treningu oraz rozgrywkach sportowych. 


\section{Analiza wyników badań}

Tabela 1. Wyniki badań

\begin{tabular}{|c|c|c|c|c|c|c|c|c|c|}
\hline $\begin{array}{l}\text { Badane } \\
\text { koszykar } \\
\text { ki }\end{array}$ & $\begin{array}{l}\text { Obwody } \\
\text { klatki } \\
\text { piersiowe }\end{array}$ & $\begin{array}{l}\text { Obwód } \\
\text { ramieni } \\
\text { a }\end{array}$ & $\begin{array}{l}\text { Długość } \\
\text { ramieni } \\
\text { a }\end{array}$ & $\begin{array}{l}\text { Szerokoś } \\
\text { ć } \\
\text { miednicy }\end{array}$ & \begin{tabular}{|l|} 
Szerokoś ć \\
barków
\end{tabular} & $\begin{array}{l}\text { Długoś } \\
\text { ć } \\
\text { tulowi } \\
\text { a } \\
\end{array}$ & \begin{tabular}{|l|} 
Długość \\
kończyn \\
dolnej
\end{tabular} & $\begin{array}{l}\text { Smukłoś } \\
\text { ć } \\
\text { sylwetki } \\
\text { ciala }\end{array}$ & BMI \\
\hline nr1 & 86 & 30 & 29 & 30 & 35 & 57 & 88 & 1,15 & $\begin{array}{c}20,4 \\
2\end{array}$ \\
\hline $\mathrm{nr2}$ & 83 & 29 & 28 & 29 & 39 & 53 & 86 & 1,16 & $\begin{array}{c}20,0 \\
5\end{array}$ \\
\hline nr3 & 93 & 30 & 34 & 32 & 37 & 58 & 100 & 1,12 & $\begin{array}{c}21,3 \\
3\end{array}$ \\
\hline nr4 & 96 & 32 & 33 & 31 & 36 & 59 & 96 & 1,17 & $\begin{array}{c}22,0 \\
7 \\
\end{array}$ \\
\hline nr5 & 90 & 28 & 30 & 30 & 36 & 56 & 90 & 1,18 & $\begin{array}{c}21,2 \\
9\end{array}$ \\
\hline nr6 & 93 & 29 & 30 & 31 & 41 & 57 & 92 & 1,16 & $\begin{array}{c}21,1 \\
3\end{array}$ \\
\hline nr7 & 85 & 27 & 28 & 30 & 35 & 52 & 85 & 1,23 & $\begin{array}{c}21,3 \\
8\end{array}$ \\
\hline nr8 & 87 & 31 & 27 & 28 & 38 & 49 & 81 & 1,24 & $\begin{array}{c}21,2 \\
0\end{array}$ \\
\hline nr9 & 95 & 32 & 31 & 30 & 35 & 57 & 94 & 1,15 & $\begin{array}{c}21,3 \\
3\end{array}$ \\
\hline nr10 & 90 & 28 & 30 & 33 & 38 & 57 & 93 & 1,17 & $\begin{array}{c}21,4 \\
9\end{array}$ \\
\hline nr11 & 88 & 27 & 29 & 29 & 35 & 54 & 88 & 1,24 & $\begin{array}{c}22,0 \\
9\end{array}$ \\
\hline nr12 & 92 & 31 & 29 & 29 & 36 & 55 & 89 & 1,20 & $\underset{3}{21,5}$ \\
\hline Srednie & 89,83 & 29,5 & 29,83 & 30,17 & 36,75 & 55,33 & 90,17 & 1,18 & $\begin{array}{c}21,2 \\
8\end{array}$ \\
\hline
\end{tabular}

Zródło: opracowanie własne

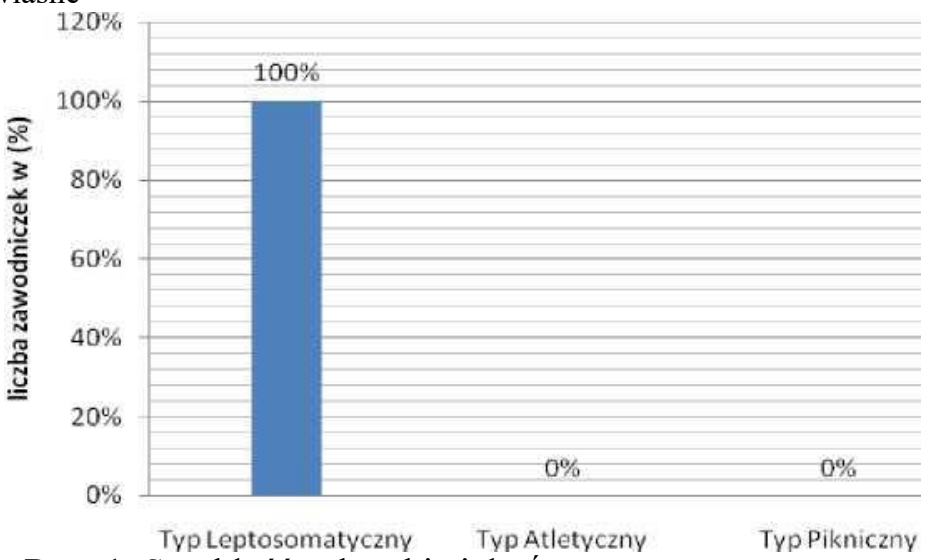

Ryc. 1. Smukłość sylwetki ciała Źródło: opracowanie własne

Z badań wynika, że wszystkie zawodniczki (100\%) charakteryzują się leptosomatycznym typem budowy ciała. Żadna $\mathrm{z}$ badanych dziewcząt nie wykazała typu atletycznego ani typu piknicznego (ryc. 1). 


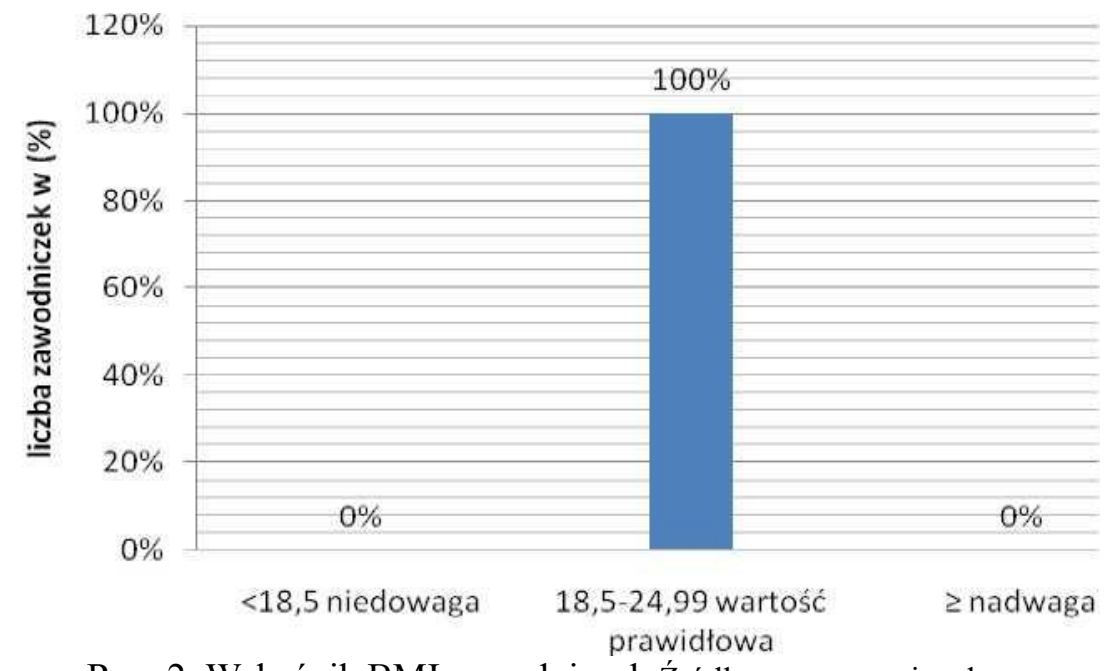

Ryc. 2. Wskaźnik BMI zawodniczek Źródło: opracowanie własne

Przeprowadzone badania wskazują, że wszystkie zawodniczki z zespołu znajdują się w grupie o wartościach prawidłowego odżywiania. (ryc. 2). 


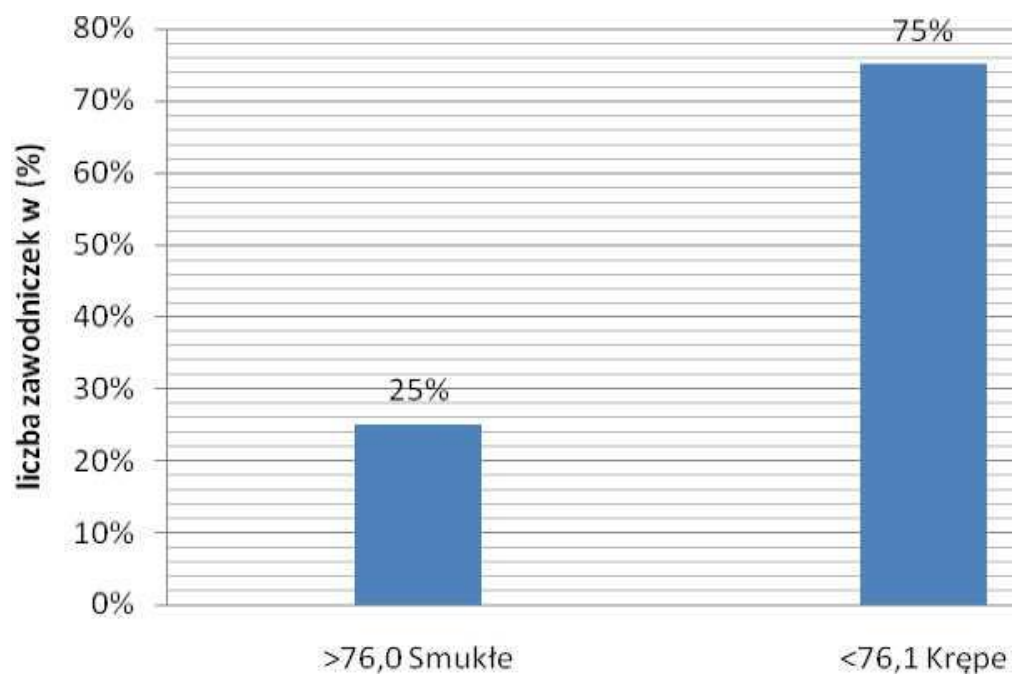

Ryc. 3. Wskaźnik umięśnienia ramienia zawodniczek Źródło: opracowanie własne

Badane koszykarki w 75\% charakteryzują się ramieniem krępym. Pozostałe zawodniczki (25\%) mają ramię smukłe (ryc. 3 ).

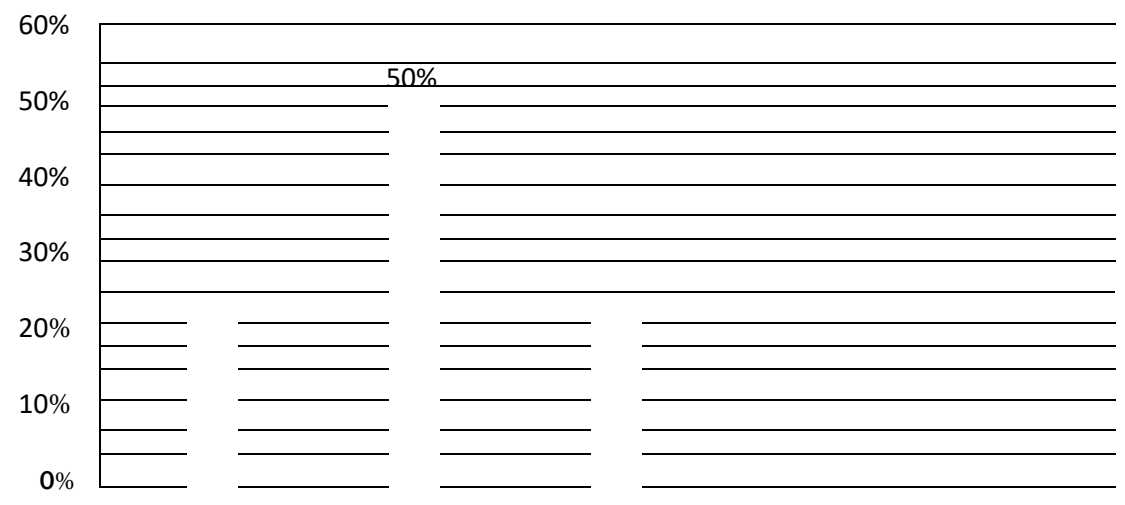

Ryc. 4. Wskaźnik Pigneta zawodniczek Źródło: opracowanie własne

$£$

g Dane zamieszczone w rycinie 4 pozwalają stwierdzić że 50\% koszykarek charakteryzuje się budową bardzo mocną, $25 \%$ dziewcząt wyróżnia się budową to bardzo mocną i $25 \%$ zawodniczek budową średnią. Żadna $\mathrm{z}$ badanych nie $\stackrel{\circ}{\mathrm{g}}$ wykazuje budowy słabej ani budowy bardzo słabej.

$\mathrm{x}-18,8$

$18,9-22,5$

22,6-30,0

$30,1-33,8$

33,9-x

Budowa Budowa Budowa Budowa słaba Budowa bardzo mocna mocnaśredniak 


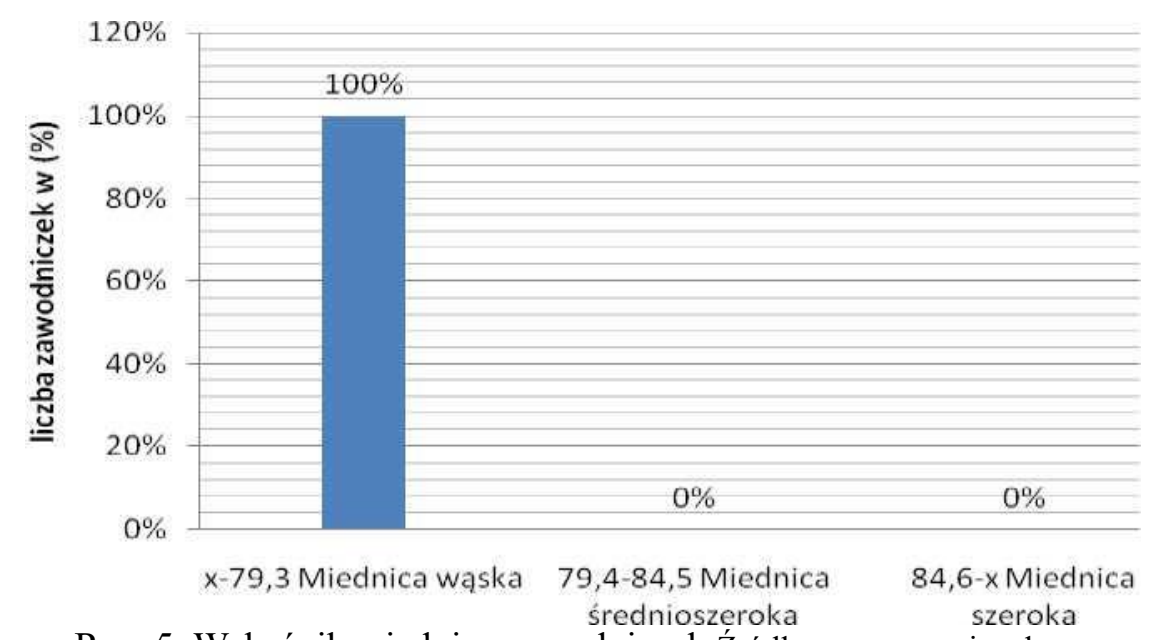

Ryc. 5. Wskaźnik miednicy zawodniczek Źródło: opracowanie własne

Przedstawione wyniki badań na ryc.5 wskazują ze 100\% koszykarek z klubu „Baton basket 25 Bydgoszcz" charakteryzują się miednicą wąską. Żadna z zawodniczek nie wykazała budowy miednicy średnioszerokiej ani szerokiej.

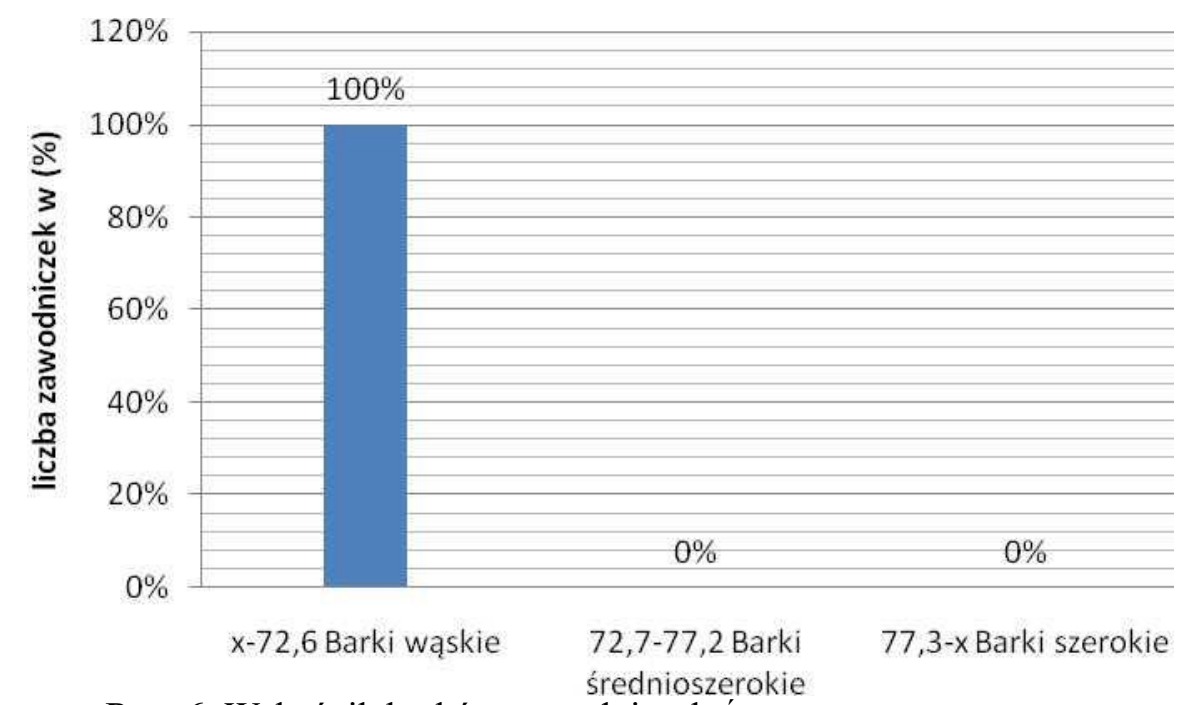

Ryc. 6. Wskaźnik barków zawodniczek Źródło: opracowanie własne

Koszykarki z bydgoskiego klubu charakteryzują się wąskimi barkami (100\%). Żadna nie wykazała typu budowy barków średnioszerokich ani szerokich. 


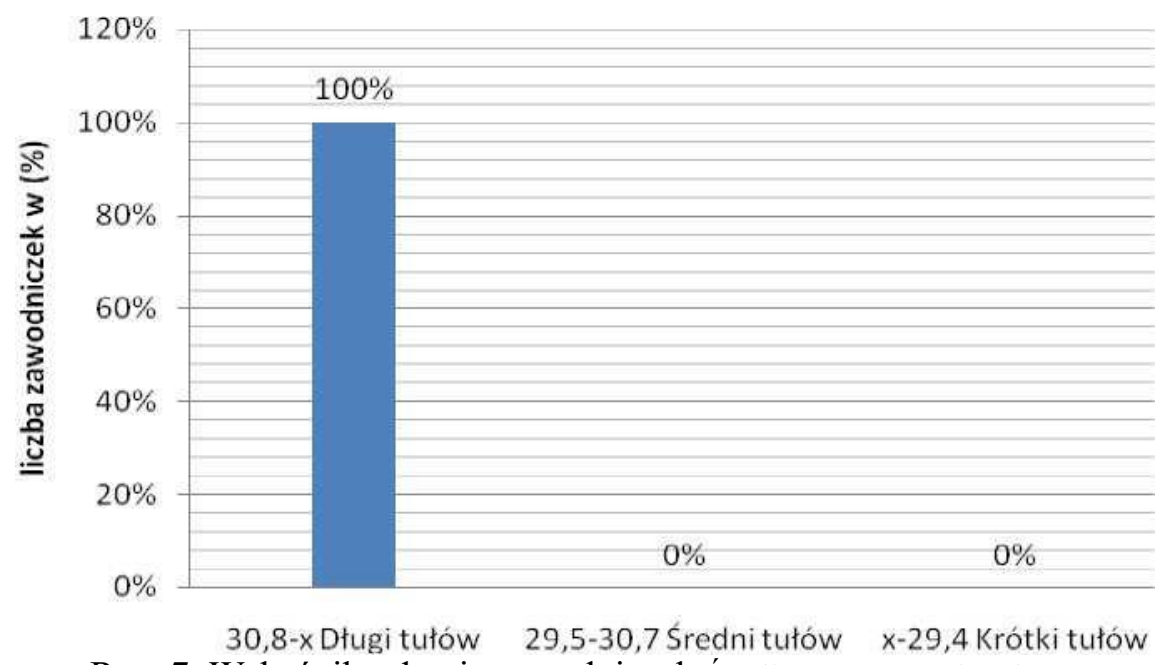

Ryc. 7. Wskaźnik tułowia zawodniczek Źródło: opracowanie własne

Z ryciny 7 wynika, że $100 \%$ koszykarek posiada długi tułów. Żadna z koszykarek nie wykazała parametrów średniego ani krótkiego tułowia.

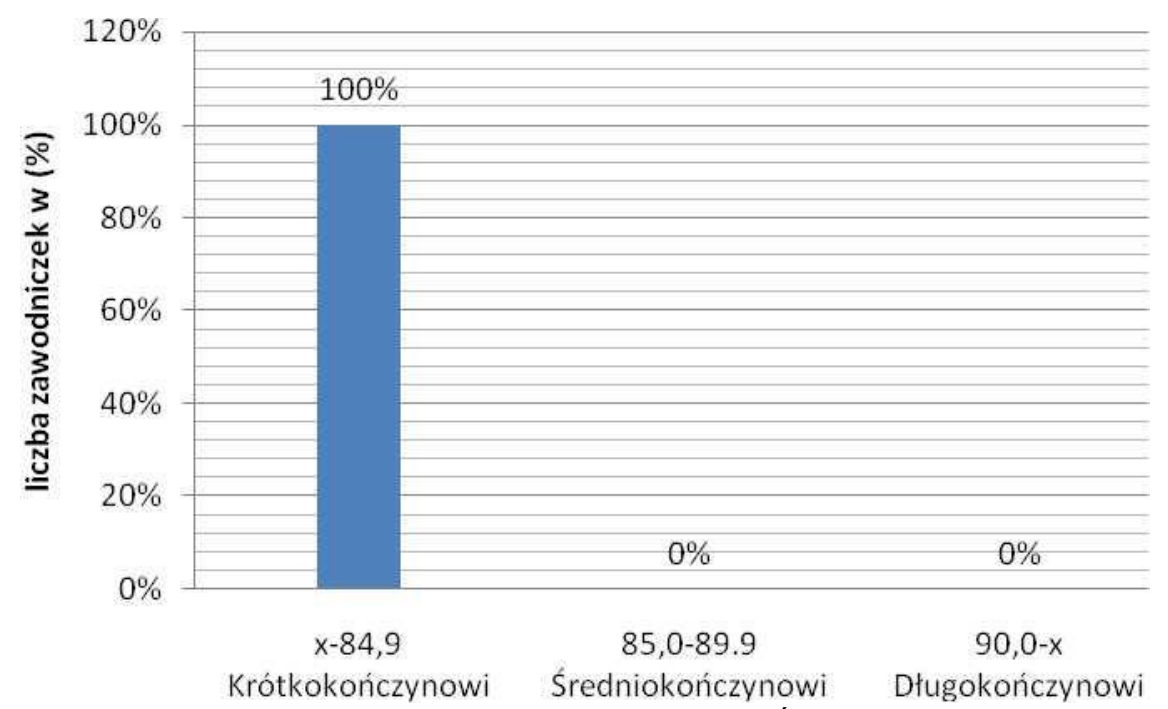

Rys. 8. Wskaźnik kończyny dolnej zawodniczek Źródło: opracowanie własne

Badane koszykarki (100\%) reprezentują grupę krótkokończynowych. Żadna z zawodniczek nie wyróżniła się cechami długokończynowymi ani średniokończynowymi (ryc. $8)$.

\section{Wnioski}

W książce Drozdowskiego(1979) Kłyszejko podaje że optymalny wzrost dla koszykarek 166-185cm (Drozdowski, 1979, s. 169). Łutowinowa i Utkina twierdza także że koszykarzy charakteryzuje wysoki wzrost ale w poszczególnych klasach rozgrywkowych oraz reprezentacjach (...) może ona wahać się $w$ dość znacznych granicach (Drozdowski, 1979, s. 170). A Borow prowadzący badania stwierdził że dla młodego koszykarza szczególnie diagnostyczne sa nastẹpujące cechy morfologiczne: wzrost, dlugość ramienia, dlugość przedramienia, ciężar ciała, dtugość kończyny górnej oraz dlugość tułowia (Drozdowski, 1979, s. 169).

Teresa Łaska-Mierzejewska uważa że (...) proporcje wysokości do masy ciała 
odgrywaja ogromna role $w$ sporcie. Duża wysokość ciała jest warunkiem niezbędnym do uprawiania koszykówki (Łaska-Mierzejewska, 1999, s. 135).

Zawodnicy uprawiający koszykówkę spośród innych dyscyplin (...) będą odznaczać się dużymi wartościami czynnika dtugości (Łaska-Mierzejewska, 1999, s. 151).

Pod względem trenowania ciało zawodniczek uprawiających koszykówkę się zmienia i nabiera cech bardziej męskich. Dzisiaj wiadomo, że męskie rozmiary i proporcje zawodniczek wielu dyscyplin sportu sa spowodowane selekcja pod katem bardziej męskiej budowy. Trening może tylko potęgować męskość budowy poprzez redukcję tkanki tluszczowej i rozwój umięśnienia (Łaska-Mierzejewska, 1999, s. 179).

Uważa się że (...) kobieta o budowie przeciętnej dla swojej ptci nie ma szans na osiagnięcia wyników na najwyższym poziomie sportowym (Łaska-Mierzejewska, 1999, s. 179). Im wyższy poziom w zespole tym dochodzi do zmniejsza cech somatycznych danej płci w danej dyscyplinie dlatego zawodniczki cechują się bardziej męską budową niż reszta populacji. Do takiej sytuacji dochodzi przez selekcje zawodniczek o słabszej budowie ciała nie wyróżniających się męskimi cechami oraz pod kwestia treningu przez co zawodniczki zmniejszają ciężar ciała i nabierają właśnie cech budowy męskiej (Łaska-Mierzejewska, 1999).

Znaczne podobieństwo budowy ciała zawodników w danej dyscyplinie jest dość znaczne ale także jest dość znaczne jeżeli będziemy spoglądać na różne poziomy sportowe. Tylko nieliczni sportowcy $\mathrm{z}$ danej dyscypliny dostają się na najwyższy szczebel a jest to uwarunkowane selekcją: Tylko selekcja eliminuje jednostki odbiegajace od wzorca morfologicznego poszczególnych dyscyplin sportu i tylko zawodnicy spetniajacych ten wzorzec widzimy w kadrze narodowej i na igrzyskach olimpijskich (Laska-Mierzejewska, 1999, s. 157).

Wiek menarche jest bardzo specyficzny i osobniczo uwarunkowany genetycznie chodź na wystąpienie pierwszej miesiączki u młodej zawodniczki trenującej lub dopiero zaczynającej trenować ma wpływ (...) obciażenia treningowe i selekcja, ale także stres oraz żywienie (LaskaMierzejewska, 1999, s. 192). Pod względem miesiączkowania poszukuje się zawodniczek, które jeszcze nie zaczęły miesiączkować ponieważ miesiączka występuje prawie zawsze po tym momencie, w którym krzywa szybkości ciała osiaga swój szczyt (Wyżnikiewicz, 1977, s. 150). Zawodniczki, które wykazywały się wysokością ciała, ale zaczęły już miesiączkować w późniejszej selekcji zostają wyeliminowane przez zawodniczki później dojrzewające, które zazwyczaj przewyższają je wzrostowo.

W koszykówce wyodrębnia się pięć pozycji do których przypisuje się różnych graczy pod względem umiejętności koszykarskich, wzrostu oraz predyspozycji do danej pozycji na boisku. Doboru zawodnika wobec dyscypliny i pozycji wykonuje się także pod względem talentu jaki i predyspozycji do określonego sportu. Czynnikami które głownie decydują o doborze do danej dyscypliny to sprawność ogólna, warunki fizyczne, umiejętności techniczne, umiejętności taktyczne, predyspozycje psychiczne, wiedza o wykonywanych czynnościach, doświadczenie zawodnicze oraz plan życiowy zawodnika (Huciński, Makurat, Wilejto-Lekner, 1998).

Pod względem predyspozycji psychologicznych zawodników dokonuje się także doboru pod względem określonej pozycji na boisku ale trzeba pamiętać (...) że każdy zawodnik to określona odrębna indywidualność. Osobowość to przecież konkretny człowiek posiadajacy indywidualne właściwości fizyczne i psychiczne (Huciński, Makurat,Wilejto-Lekner, 1998, s. $62)$.

Ogólnie (...) koszykarze jako typowi przedstawiciele gier zespołowych ceniq sobie atmosferę wspótpracy i wzajemnego zrozumienia (Huciński, Makurat, Wilejto- Lekner, 1998, s. $63)$.

W koszykówce według (Wyżnikiewicz, 1978) najpierw poszukuje się zawodniczek wysokich a następnie przez trening pobudza się $\mathrm{w}$ nich zainteresowanie tym sportem. 
Koszykarki generalnie charakteryzują się szczupła budową ciała ponieważ przesądza o tym wysoka budowa ciała. Uważa się że jest to budowa charakteryzująca sportowców leptosymatycznych.

Rekrutacja dzieci do gry w koszykówkę może odbywać się w szelaki sposób. Według Waleriana Klimontowicza selekcja odbywa się na poszczególnych etapach rozwoju dziecka przez różne metody. Na początku zaciekawia się dzieci samą treścią, historią, teorią koszykówki poprzez puszczanie ciekawych filmów czy też plakatów, albo zapraszaniu na treningi czołowych zawodników najwyższej ligi w kraju lub danego miasta. Następnie przez różne zabawy bieżne rzutne i zręcznościowe na różnym poziomie poprzez mini koszykówkę w szkole oraz na szczeblu miedzy szkolnym obserwuje się dzieci. Drugim sprawdzeniem może być wewnątrz szkole rozgrywki czyli podzielenie danej grupki dzieci i obserwacja oraz protokołowanie ich reakcji czynów wobec tych gier. Na dalszym etapie przechodzi się do obserwacji charakterystycznych jak dla koszykówki umiejętności takie jak chwyt, podanie i rzut oraz wywiad z rodzicami.

System organizacji szkolenia w koszykówce młodzieżowej na podstawie materiałów z PZKosz program rozwoju polskiej koszykówki opisują Tedeusz Huciński i Edyta Kisiel (2008) w książce szkolenie dzieci i młodzieży w koszykówce. Polega on na obiciu szkoleniem dzieci od przedszkola przez szkołę podstawową, gimnazjum aż do trzeciej liceum. Młodzi zawodnicy szkolą się pozalekcyjnie pod okiem trenerów uczęszczając także na obozy letnie oraz biorąc udział w turniejach wewnętrznych na szczeblu wojewódzkim i ogólnopolskim. Spośród utalentowanych zawodników $\mathrm{w}$ drużynie wybiera się poszczególne jednostki do reprezentowania kadry wojewódzkiej oraz kadr narodowych takich jak U12, U13, U14, U15 itd.. Następnie po ukończeniu gimnazjum wybiera się z całego kraju zawodników szkól mistrzostwa sportowego tam szlifowane są tzw. diamenty przyszłego dorosłego basketu.

Według Tadeusza Hucińskiego (1998) normatywny zawodnik grający w gry zespołowe uwzględniając techniczno-taktyczne uwarunkowania powinien wykazywać się cechami:

-ogólnie stosowanie nawyku sprawdzającego siebie, drużynę i zespół, grupę,

-nie kreowanie się egoizmem lecz kierowanie się dobrem zespołu i ogółu, -stawienie sobie celu nadrzędnego oraz identyfikacji się ze zespołem i pozytywne nastawienie wobec niego.

Z badań wynikają następujące wnioski:

1. Wszystkie koszykarki charakteryzują się typem leptosomatycznym.

2. Wszystkie (100\%) zawodniczki posiadają wartość wskaźnika BMI na poziomie wagi prawidłowej.

3. Przeważa ramie krępe (75\%), a (25\%) posiada ramie smukłe.

4. Budową bardzo mocną charakteryzuje się 50\% koszykarek, 25\% wyróżnia się budową bardzo mocną i $25 \%$ zawodniczek budową średnią.

5. Miednicą wąską i wąskimi barkami charakteryzuje się 100\% koszykarek.

6. Wszystkie (100\%) koszykarki posiadają długi tułów.

7. Badane koszykarki (100\%) reprezentują grupę krótkokończynowych.

\section{Piśmiennictwo}

1. Drozdowski Z. (1979). Antropologia sportowa, Państwowe Wydawnictwo Naukowe Oddział - W, Poznań.

2. $\quad$ Drozdowski Z. (1998). Antropometria w wychowaniu fizycznym. AWF, Poznań.

3. Drozdowski Z. (2002). Antropologia dla nauczycieli wychowania fizycznego, AWF, Poznań.

4. Huciński T., Makurat F., Wilejto-Lekner I. (1998). Kierowanie treningiem $i$ walka 
sportowa w koszykówce. Gra w obronie, AWF, Gdańsk.

5. Huciński T., Kisiel E. (2008). Szkolenie dzieci i młodzieży w koszykówce, Biblioteka Trenera, Warszawa.

6. Laska-Mierzejewska T. (1999). Antropologia $w$ sporcie $i$ wychowaniu fizycznym, Biblioteka Trenera, Warszawa.

7. Malinowski A., Władimir B. (1997). Podstawy antropometrii. Metody, techniki, normy, PWN, Warszawa.

8. Sozański H., Zaprożanow W. (1997). Dobór i kwalifikacje do sportu, Biblioteka Trenera, Warszawa.

9. Wyżnikiewicz Z. (1977). Koszykówka dzieci i młodzieży. Wydawnictwo Sport i Turystyka. Warszawa.

\section{Cel podjętych badań}

W dzisiejszych czasach poszukuje się zawodników którzy będą rokować na przyszłość w danej dyscyplinie. Obecny poziom rekordowych osiagnięć w większości dyscyplin dostępny jest jedynie dla zawodników dysponujących dobrym zdrowiem, szczególna budowa ciała, wysokim poziomem cech fizycznych, sprawności funkcjonalnej i właściwości, które determinuja sukces w określonej dyscyplinie sportu (Sozański, Zaprożanow, 1997, s. 7). Dlatego na samym początku do określenia perspektyw rozwoju początkujących sportowców na bazie cech morfologicznych powstaje konieczność oceny zgodności ich budowy ciała z analogicznymi właściwościami mistrzów sportu (Sozański, Zaprożanow, 1997, s. 46).

Najbardziej przyjmowaną i popularną budową ciała jaką charakteryzują się koszykarze według Drozdowskiego(1979) jest (...) bardzo wysoki wzrost i znaczny stopień smukłości ciała (Drozdowski, 1979, s. 168).

Badaniami antropologicznymi objęto koszykarki z bydgoskiego klubu sportowego pod nazwą „Baton Basket 25 Bydgoszcz”. Przebadanych zostało 12 zawodniczek grających na poziomie Pierwszej Ligi Centralnej Kobiet w kraju. Niektóre z nich zaliczane zostają także do składu ekstraklasy w danym klubie.

(wysokość ciała $\mathrm{w} \mathrm{cm})^{3}$

Formuła Curtiusa:

Typ leptosomatyczny $\quad-\mathrm{x}-1,27$

Typ atletyczny - $\quad 1,28-1,49$

Typ pikniczny - $\quad 1,50-\mathrm{x}$

Wyniki posłużą do określenia typu budowy ciała każdej zawodniczki.

Obliczono również wskaźnik BMI określający sposób odżywiania wg wzoru:

$$
\text { BMI__masa }(\mathrm{kg})_{-}
$$

$<18,5$ - niedowaga

$\operatorname{wysokosc}(m)^{2}$

18,5-24,99 - wartość prawidłowa

$>25,0$ - nadwaga

Wskaźnik umięśnienia ramienia: $\mathrm{I}=($ obwód : długość) $\mathrm{x} 100$

Uzyskane wyniki określą: ramię smukłe dla kobiety odpowiednio $>76,0$; krępe $<76,1$

Wskaźnik Pigneta wielkości wskaźnika sklasyfikowane zostały na podstawie polskich materiałów utworzonych z badań kandydatów na studia wychowania fizycznego.

Obliczenia dokonano wg wzoru I = wysokość ciała - (masa + obwód klatki piersiowej). Dla kobiet: budowa bardzo mocna $\mathrm{x}$ - 18,8; budowa mocna 18,9- 22,5; budowa średnia 22,6 30,0; budowa słaba 30,1 - 33,8; budowa bardzo słaba 33,9 - x.

Wskaźnik tulowia: $\mathrm{I}=($ długość tułowia $:$ wysokość ciała $)$ x 100. Kryteria dla kobiet: długi tułów 30,8 - x; średni tułów 29,5 - 30,7; krótki tułów x - 29,4: 
Wskaźnik barków: $\mathrm{I}=($ szerokość barków : długość tułowia) x 100. Kryteria dla dla kobiet: barki wąskie x - 72,6; barki średnioszerokie 72,7 - 77,2; barki szerokie 77,3 - x .

Wskaźnik miednicy: $\mathrm{I}=$ (szerokość miednicy : szerokość barków) x 100. Kryteria dla kobiet: miednica wąska x - 79,3; miednica średnioszeroka 79,4 - 84,5; miednica szeroka 84,6 $\mathrm{x}$.

Wskaźnik kończyny dolnej wg wzoru: (długość kończyny dolnej : wysokość ciała) x 100. Wartości x-84,9 krótkokończynowi, 85,0-89,9 średnikończynowi, 90,0-x długokończynowi 